\title{
Plague, Practice, and Prescriptive Text
}

\section{Jewish Traditions on Fleeing Afflicted Cities in Early Modern Ashkenaz}

\author{
Moshe Dovid Chechik* \\ Hebrew University, Jerusalem, Israel \\ moishi.chechik@mail.huji.ac.il \\ Tamara Morsel-Eisenberg** \\ Harvard Society of Fellows, Cambridge, Massachusetts, United States \\ mtamara@fas.harvard.edu
}

\begin{abstract}
This article studies the fate of a contradiction between practice and prescriptive text in 16th-century Ashkenaz. The practice was fleeing a plagued city, which contradicted a Talmudic passage requiring self-isolation at home when plague strikes. The emergence of this contradiction as a halakhic problem and its various forms of resolution are analyzed as a case study for the development of halakhic literature in early modern Ashkenaz.

The Talmudic text was not considered a challenge to the accepted practice prior to the early modern period. The conflict between practice and Talmud gradually emerged as a halakhic problem in 15 th-century rabbinic sources. These sources mixed legal and non-legal material, leaving the status of this contradiction ambiguous. The 16th century saw a variety of solutions to the problem in different halakhic writings, each with their own dynamics, type of authority, possibilities, and limitations. This variety reflects the crystallization of separate genres of halakhic literature.
\end{abstract}

* Moishe Dovid Chechik is a historian of halakha in Medieval Ashkenaz. He received his MA cum laude at the Talmud Department of the Hebrew University of Jerusalem. His thesis won the Polonski Prize for originality and creativity. He is currently writing his $\mathrm{PhD}$ at the Hebrew University, where he won the Dean's Fellowship for outstanding students.

** Tamara Morsel-Eisenberg is a historian of Early Modern Jewish cultural and intellectual history in Europe. She defended her PhD, titled The Organization of Halakhic Knowledge in Early Modern Europe: The Transformation of a Scholarly Culture at the University of Pennsylvania's history department in 2018. She is currently a Junior Fellow at the Harvard Society of Fellows. 


\section{Keywords}

Jewish law - early modern - plague

The Talmud (вт Bava Qamma 6ob) addresses proper conduct during plague and famine. Regarding the latter, "famine in the city, scatter your feet [i.e., flee]." Regarding the former, "plague in the city, gather your feet [i.e., go indoors]." The preference of the Talmud for sheltering in place during times of plague is unambiguous, yet late medieval and early modern sources abundantly attest that during times of plague, many Jewish city-dwellers would flee until the danger had passed. The Jews who fled plague included some of the leading rabbis of those eras. For instance, one of the best-known attestations to this phenomenon was penned by Rabbi Moshe Isserles (Rema): ${ }^{2}$

I, Moshe, [...], called Isserles from Krakow, was in the exile to which we fled from our city in $5316\left[=155^{6}\right]$, due to the stench of the air, ${ }^{3}$ may it not

1 This article is dedicated to Elchanan Reiner, who taught us so much about the culture of early modern Ashkenazic halakhah, and sparked this intellectual collaboration.

The article has two antecedents: Moshe David Chechik, "Ha-Issur o ha-Hovah Livro'ah min ha-Ir be-Sha'at ha-Magefah" ("The Prohibition or the Obligation to Flee the City During an Epidemic"), 6o(3) HaMa'ayan (2020), 22 (Hebrew); Tamara Morsel-Eisenberg. "Is it Permitted to Flee the City?" 2020. Tablet Magazine. Retrieved 23 Jun 2020, tabletmag.com/sections/ history/articles/coronavirus-16th-century-rabbis.

The authors are thankful to Elli Fischer for masterfully editing the writing of two authors to produce a seamless whole. Moreover, his passion for the topic and grasp of the material resulted in significant contributions and substantive insights throughout the article. The insightful comments of Judah Galinsky, Pawel Maciejko, Daniel R. Schwartz, and Shaul Stampfer are much appreciated. The authors are grateful to the Memorial Foundation for Jewish Culture for providing a grant supporting this article

2 Rema died in Krakow, having lived there his whole life, in May 1572, at approximately fifty years of age. He was a judge on the local rabbinical court and is considered one of the greatest rabbis in Poland. Mapah, Rema's glosses on Shulhan Arukh, resulted in the acceptance of this code by Ashkenazic Jews. See, Elchanan Reiner, "The Ashkenazi Élite at the Beginning of the Modern Era: Manuscript Versus Printed Book", 10 Polin: Studies in Polish Jewry (1997), 85; on Rema, see Asher Siev, Rabbi Moses Isserles (Ramo) (Yeshiva University Press: New York, 1972) (Hebrew); Asher Siev, "Rema as a Jewish Adjudicator and Decisionmaker", 25 Ha-darom (1967), 211 (Hebrew).

3 "Ipush ha-avir" ("stench of the air") and similar Hebrew terms are equivalent to "miasma." Miasmatic theory, which attributed epidemics to airborne particles of decomposing matter, persisted as a functional medical paradigm until well into the modern period, often alongside theories of contagion. See, for instance, the introduction in: Annemarie Kinzelbach, 
befall us. We were sojourners in a land not ours in the city of Shidlov, ${ }^{4}$ where there is neither fig tree nor grape vine, and barely any water to drink, [...]; a city where bread is scarce and where there is no wood with which to keep warm. ${ }^{5}$

Thus, there was a clear gap between the conduct prescribed by the Talmud and the behavior of Jews during plagues. The present study describes how latemedieval rabbis and later the first generations of Polish-Ashkenazic rabbis, in the 16th century, addressed the practice of fleeing from the plague. ${ }^{6}$ It analyzes how these rabbis attempted to reconcile the prevailing practice with the text of the Talmud in their writings, and to determine the proper course of action for their communities and themselves during the all-too-frequent outbreaks.

The problem faced by the rabbis was simultaneously exegetical, theological, and halakhic (relating to Jewish religious law). ${ }^{7}$ It had a textual, theoretical dimension of harmonizing disparate ideas, sources, laws, and traditions, but it was also a concrete, urgent matter of life and death. Some sources touch upon theological issues, grappling with questions about the relationship between Divine providence and human endeavor in the face of catastrophe. This multifaceted problem affords us a glimpse "backstage," where these rabbis contended with a disparate array of considerations and sources as they attempted to explain and even prescribe seemingly problematic behavior. This view, in turn, exposes some important developments in the modes of rabbinic writing and halakhic reasoning in early modern Ashkenazic culture.

The development we trace covers about two centuries. The practice of fleeing first appears in a halakhic context in the early 15 th century, in a responsum

"Infection, Contagion and Public Health in Late Medieval and Early Modern German Imperial Towns", 61(3) Journal of the History of Medicine and Allied Sciences (2006), 369.

4 Szydłów, Poland, approximately 100 km northeast of Krakow.

5 Rema, Mehir Yayin (Cremona: Vincenzo Conti, 1559), Introduction. This book is a commentary on the Scroll of Esther that Rema composed and sent to his father in lieu of the portions of food usually exchanged on Purim, which his displacement rendered impossible. Asher Siev, in the introduction to his edition of Responsa Rema (Jerusalem: Hemed, 1971), 36-39, cited several additional attestations to the phenomenon of fleeing plague in 16th-century Europe.

6 The parameters of this study are chronologically limited to sources about fleeing during epidemics written in the 16th century, with some background on the late Middle Ages and an epilogue glancing ahead to the 17 th century. Its geographic focus is the Ashkenazic sphere. These boundaries serve the purpose of our larger inquiry into the development of Jewish legal literature in the early modern period. There are no comparable Sephardic sources addressing this issue as a halakhic problem.

7 The term "halakhah" (pl. "halakhot"), generally translated as "Jewish law," covers a range of discourses, normative modes, and applicability. See: Chaim Saiman, Halakhah: The Rabbinic Idea of Law (Princeton: Princeton University Press, 2018), 17-73. 
that embeds the Talmudic passage about sheltering in place within an undifferentiated assortment of sources, observations, and discourses. As we turn to the 16th century, however, we witness the crystallization of distinct rabbinic literary genres, such as commentaries, legal glosses, codes, responsa, and sermons. Each of these genres acknowledges the primacy of fleeing, but when justifying the practice, each employs a mode of discourse that differentiates that genre from the others. This development, we argue, typifies a broader trend in early modern Ashkenazic rabbinic writing.

As noted, the prevailing practice of fleeing the city directly contravenes the Talmudic instructions for times of plague (в т Bava Qamma 6ob):

The Sages taught: If there is plague in the city, gather your feet, as it is stated: "And none of you shall go out of the opening of his house until the morning" (Exodus 12:22). And it is stated: "Come, my people, enter into your chambers, and shut your doors behind you; hide yourself for a little moment, until the tempest has passed" (Isaiah 26:20). And it is stated: "Outside the sword will bereave, and in the chambers - terror" (Deuteronomy 32:25).

This early Tannaitic baraita consists of a pithy instruction — "plague in the city, gather your feet"-followed by three prooftexts from Scripture. The first, from Exodus, expands Moses's instruction to the Israelites to remain indoors during the Plague of the Firstborn to all instances of plague. The Talmud then clarifies the need for the other two prooftexts as well. The first verse addresses only the night, so the second verse, from Isaiah, is needed to teach that "gather your feet" applies as long as the tempest rages, be it day or night. The third verse teaches that even if remaining indoors may cause terror, one must remain inside.

The Talmud then relates the practice of a prominent sage:

At a time of wrath [i.e., plague], Rava would board up the windows, as it is written: "For death is come up into our windows" (Jeremiah 9:20).

Subsequently, the Talmud discusses the proper practice in times of famine:

The Sages taught: If there is famine in the city, scatter your feet [i.e., flee], as it is stated: "And there was a famine in the land; and Abram went down into Egypt to sojourn there" (Genesis 12:10). And it is stated: "If we say:We 
will enter into the city, then the famine is in the city, and we shall die there" (II Kings 7:4) ...

The Sages taught: If there is a plague in the city, one should not walk in the middle of the road, because the Angel of Death walks in the middle of the road...

When there is famine in the city, one must flee. In the case of a plague, however, isolating indoors is the prescribed course of action.

The Talmud contains a broad variety of hortative statements carrying different levels of normative weight. At one end is absolute, binding halakhah, and at the other extreme are folk sayings, medical recommendations, and general advice - a loose grouping of nonlegal contents known as Aggadah ("lore"). Between these extremes are customs, traditions, and other statements whose degree of normativity is ambiguous, indeterminate, or somewhere along the spectrum between law and lore. Moreover, the associative organization of the Talmud and abrupt transitions between different types of statements often make it difficult to classify, and thus ascertain the degree of normativity, of any particular dictum.

The instructions of the Talmud for times of plague and famine seem, prima facie, to fall squarely on the halakhic end of this spectrum. They exhibit several features of matters of law. The Babylonian redactors of the passage begin by quoting the baraitot - teachings attributed to the Tanna'im, the earliest rabbis, who lived in the first centuries of the common era and whose statements are almost always deemed normative and authoritative. Moreover, in this case, the baraitot also bolster their practical instructions with biblical prooftexts. Finally, the Talmud reports that Rava, a central figure in the Babylonian Talmud whose views are almost always accepted as binding law, not only followed the tannaitic instructions to the letter, but even went beyond them by covering his windows as well.

It is noteworthy, then, that these instructions do not appear in any postTalmudic halakhic work until the 15th century. They are not included in any halakhic composition from the Geonic period (late first millennium), nor in any of the three main medieval halakhic codes - Halakhot of Rabbi Yitzhaq Alfasi ("Rif"; 11th century), Maimonides's Mishneh Torah (late 12th century), and Halakhot of Rabbi Asher ben Yehiel ("Rosh"; late 13th/early 14th century). They are also absent from Ashkenazic halakhic compositions and compendiums, from Sefer Ha-Turim ("Tur") of Rabbi Ya'aqov, the son of Rabbi Asher, who reorganized material from the codes of Rif, Maimonides, and Rosh into a practical code.

The primary traditional litmus test of what constitutes a halakhah is inclusion in halakhic codes, and the codifiers did not include the directives that 
appear in Bava Qamma 6ob. The binary division of Talmudic material into halakhah and aggadah, ${ }^{8}$ and the exclusion of aggadah from legal discourse, crystallized after the Talmudic period. This division appears in the Geonic academies and was systematized by Rif, who omitted aggadah from his Halakhot - organized as a halakhic synopsis of the Talmud. Any Talmudic dictum omitted by Rif and subsequent halakhic codes was, by definition, considered aggadic. Evidently, the statements on plague, despite having the literary trappings of halakhah, were deemed nonbinding aggadah.

At the same time, none of the codes or halakhic works prescribe any alternative to the Talmud's instructions for times of plague. How Jews did respond to plague is not in evidence anywhere in rabbinic literature from the close of the Talmud until the 13th century, at the earliest, and there is no record of any attempt to reconcile the instructions of the Talmud with common practice.

One may speculate as to why there was no attempt at reconciliation. For the purposes of this study, the relevant fact is that after the close of the Talmud, there is no record of how Jews should or did respond to plague. And as for the conflict between Talmudic instructions and common Jewish practice is concerned, the first attempts at reconciliation appear only in the early $15^{\text {th }}$ century.

Two medieval Ashkenazic sources mention the practice of fleeing from plague. One is difficult to date but is certainly not older than the 13th century, whereas the other was composed around the turn of the 15th century. Both sources mention, and even encourage, flight from plague. One attempts to reconcile this practice with the instructions of the Talmud, while the other offers a distinction that can serve to solve the apparent contradiction.

\subsection{Sefer Hasidim}

The earliest rabbinic source to addresses the phenomenon of fleeing plague is the 13th-century (at the earliest) Sefer Hasidim: ${ }^{9}$

8 The terminology of halakhah and aggadah appears in the earliest rabbinic literature, but the Talmud rarely assigns its contents to one of these two categories explicitly. For an English summary of the division of the Talmud into halakhic and aggadic components, and the exclusion of aggadah from halakhic discourse, see: Yair Lorberbaum, In God's Image: Myth, Theology, and Law in Classical Judaism (Cambridge: 2015), 62-64.

9 Sefer Hasidim is a collection of various compilations of personal practices (not customs) and observances. It is attributed to the circle of Ashkenazic pietists centered in Regensburg 
If there is plague in the city, and one heard that things are well in another city, they should not go there, for the Angel of Death has power over those who originate in that land, even aliens, so when caravans travel from a plagued city to a different land, it is smitten. However, if individuals go, and their intention is not commercial, it will not cause harm, and they are acting wisely. Anyone who wishes to escape should go to another land until the plague is arrested, and "May He destroy death forever" (Isaiah $25: 8) .{ }^{10}$

The author of this passage distinguishes between organized flight in a caravan - which causes the plague to spread to the country of destination as well - and individuals, who are wise to flee. This distinction justifies fleeing a plagued city, which can thus be formulated as a sweeping recommendation: "Anyone who wishes to escape should go to another land until the plague is arrested." The passage does not address the directives of the Talmud at all. Rather, it asserts that groups of people should not flee to an unafflicted city and explains why: the Angel of Death expands his territory through the movement of large groups and merchandise.

The mention of the Angel of Death in this instance highlights just how difficult it is to disentangle the different strands of thinking about epidemics present in these sources. To begin with, the Angel of Death is already present in the Talmudic discussion, rendering it difficult to distinguish whether the mention of this figure in later sources is a mere linguistic continuity, a paraphrase, or a discussion of the Talmud. Furthermore, the Angel of Death could be read as a substitute for the plague itself, a way of speculating about how disease travels and spreads. In this sense, the discussion is about the empirical reality of plagues and the practical question about the efficiency of fleeing. In the case of Sefer Hasidim, then, the mention that groups should not flee may simply reflect their empirical knowledge-derived experience and observation that large groups fleeing from one city to another often took the plague with them, whereas individuals did so less frequently. The Angel-of-Death theory may have been an explanation of the facts for the authors of Sefer Hasidim, just as miasmatic theory was for Rema in the 16th century, and as microbial theory

during the 13th century. One of these compilations, which had many later additions that were not part of the original Sefer Hasidim, was printed in Bologna in 1487. The edition generally considered to be the most reliable is Mekize Nirdamim, printed in 1891-1893 (see next note). Additional versions remain in manuscript. See also, Ivan G. Marcus, Sefer Hasidim and the Ashkenazic Book in Medieval Europe (Philadelphia: UPenn Press, 2018).

10 Sefer Hasidim (Wistinetzki-Freimann (ed.), Frankfurt aM: Mekize Nirdamim, 1891-1893), $\S 372$. 
has been since the 19th century. Third, the Angel of Death has a religious role as Divine agent who collects souls destined for death. Following that connotation, the discussion is not just about how disease spreads in a pseudo-scientific way, but also about the theological question of Divine justice and providence versus personal initiative and action. ${ }^{11}$ Sefer Hasidim makes no attempt to overtly explain why only group movement expands the territory over which the Angel of Death holds power. This is consistent with the genre to which Sefer Hasidim belongs: non-legal folk literature. Accordingly, it does not address the Talmudic directives and does not attempt to ground the dynamics of the Angel of Death's territoriality in any explicit theology. It addresses only the practical aspects: when fleeing is effective and how individuals can save themselves.

The multiple strands of thought - legal, theological, practical — reappear in many of the sources of this article, sometimes explicitly, at other times merely implied. Often, the different layers of meaning cannot be separated successfully, nor would doing so properly reflect their multivalence.

\subsection{Responsa Maharil}

The first source to register the disparity between the common practice of fleeing and the directives of the Talmud is a responsum - a letter written by a rabbi in response to a query, often from another rabbi - by Rabbi Ya'aqov ben Moshe Moellin (Maharil, c. 1365-1427), the leading Ashkenazic halakhist of the early $15^{\text {th }}$ century. ${ }^{12}$ His responsum is addressed to Rabbi Yehudah Loewe. ${ }^{13}$ Maharil opens his answer by paraphrasing the question at hand (which we no longer have), then presents a brief collage of sources. We present them section by section, with our comments interspersed: ${ }^{14}$

11 This theological problem did not concern only Jewish scholars. It was likewise treated by Christian and Muslim thinkers. In Islam, the directive was generally not to flee the plague, even though many did so in practice. Martin Luther also dealt with this problem, for instance: Martin Luther, "Whether One May Flee from a Deadly Plague," in Luther's Works, Vol. 43, [G. K. Wienke (ed. \& trans.), Philadelphia: Fortress Press, 1968], 115-138.

See also: Joseph P. Byrne, Encyclopedia of the Black Death (ABC-CLIO, 2012): "Flight," 146148; "Luther, Martin," 218-219; "Islamic Religious Responses," 188-189. We thank Joel Binder for this reference.

12 On Maharil, see Yedidya Dinari, Hakhme Ashkenaz be-Shilhe Yeme ha-Benayim: Darkhehem, ve-kitvehem ba-Halakhah (The Sages of Ashkenaz at the End of the Middle Ages: Their Ways and Their Writings in Halakhah) (Jerusalem: Bialik, 1984) (Hebrew); Israel Peles, Introduction to the Books of Maharil (Jerusalem: Machon Yerushalayim, 2016).

13 He is possibly Maharil's disciple, Rabbi Yehudah Loewe Landau, whose son, Rabbi Ya'aqov, authored the halakhic code Sefer Ha-Agur.

14 She'elot U-Teshuvot HaRav Ya'aqov Segal - Maharil (Cremona, 1556), §50, 13 a.

This responsum is numbered as $\$ 50$ in nearly all printed editions. In the Machon Yerushalayim edition [Responsa of Rabbi Yaacov Molin - Maharil (Yitzchok Satz (ed.), Jerusalem: 
[A] Regarding what you wrote that it is apparently forbidden to flee, and so on. In the chapter "Zeh Borer" [вт Sanhedrin 29a] we say: "Seven years there was a pestilence, yet no one died before his time." This implies, somewhat, that one should not flee.

In other words, if, as the Talmud states in this passage, people do not die before their time, then fleeing would be pointless and even an act of evading divine will. Maharil continues weighing this issue of divine providence by presenting another Talmudic passage, this one offering a different view of fate:

[B] However, it seems that this is simply a popular aphorism, for in the first chapter of [вт] Hagigah [4b], we say, "There are those who are swept away without justice," as in the case where [the Angel of Death] said to his emissary, "Go bring me Miriam, braider of women's hair..." which it states there.

The Talmudic source in вт Hagigah reads the verse, "There are those who are swept away without justice" (Proverbs 13:23) as suggesting that the Angel of Death and his agents are prone to error. For once he asked his emissary to bring — that is, to kill — Miriam megadla - i.e., braider — of women's hair, and instead the emissary killed Miriam megadla - i.e., teacher - of children. Evidently, the righteous are at risk of undeserved death even under normal circumstances. This is all the more so, Maharil explains, in a case like the plague, where the Angel of Death is given permission to do as he pleases, without distinguishing the righteous from the wicked. Maharil supports this with the source from the Talmud discussed at the opening of our article:

And we expound [in вт Bava Qamma 6oa] from the verse, "None of you shall go out of the opening of his house until the morning' teaches that once power has been given to the destroyer he does not distinguish between the righteous and the wicked."

This leads Maharil to conclude the following, before bringing additional sources and justifications:

[C] For this reason, it is common to flee.

[D] It is also evident from Sefer Hasidim, authored by the Roqe'ah, that it is good to flee.

Machon Yerushalayim, 1979), 43], it is numbered §41 and printed as one responsum with another entry that discusses a related issue. 
Rabbi Elazar ben Yehudah of Worms (died c. 1230), known as "The Roqe'ah" (Perfumer) after his halakhic work, was one of the most prominent members of Ashkenazic pietistic circles, of which Sefer Hasidim is the most famous. Maharil identified the Roqe'ah as the author of Sefer Hasidim. ${ }^{15}$ He supports these sources with further explanations. Maharil elliptically cites two verses that support the claim that calamity can befall a specific place yet spare another place nearby. The implication is that by fleeing, it is possible to escape calamity.

[E] There is good reason for this, as sometimes the decree is against one city or one country... ${ }^{16}$

The next sections of the responsum (which we skip here) address mourning customs in times of panic and plague, after which Maharil returns to the question of whether fleeing is effective, presenting two Talmudic passages that advise people to avoid dangerous situations, which can lead to premature death. The implication is that by fleeing one can indeed evade a terrible fate:

[H] We further say [вт Shabbat 32a et al.]: "A person should not stand in a dangerous place..." And we further say [Bт Berakhot 55a]: "Three things recall a person's sins: A collapsing wall..."

Next, Maharil presents testimony for the actions of authoritative figures, attesting that he has seen great sages who fled during plagues:

[I] Further, I have seen great men who went elsewhere.

Finally, Maharil arrives at the problematic Talmudic passage:

[J] Regarding what we say in the chapter "HaKones" [sixth chapter of вт Bava Qamma 6ob]: "Gather your feet,"which is derived from many verses,

15 Contemporary scholarship considers the author of Sefer Hasidim to be Rabbi Judah the Pious (d. 1317). See Marcus, supra note 8.

16 The continuation of this passage provides the verses from scripture: "[Whoever remains] in this city [shall die by the sword, by famine, and by pestilence; but] whoever leaves shall at least gain his life" [Jeremiah 21:9]. And it is written: "[I therefore withheld the rain from you three months before harvesttime:] I would make it rain on one town [and not on another; one field would be rained upon while another on which it did not rain would wither]" [Amos 4:7]. Subsequently, Maharil explains that the same principle of localized disaster applies to other types of calamity. 
I heard from our teacher, Rabbi Shalom, may he live, that once [the plague] has begun and has taken hold, and [the Angel of Death] has been given permission to go out openly, one should gather his feet.

We likewise say [Pт Berakhot 4:4]: "All roads are presumed dangerous."

However, at the beginning [of the plague], it is good to flee. Maharil, citing Rabbi Shalom of Wiener-Neustadt (d. 1413), differentiates two stages of plague within the city. During the first stage, before the plague intensifies, the proper course of action is flight. The Talmud's directive, "Gather your feet," applies later, once it has become dangerous to go out onto the roads. The common practice, therefore, does not contradict the Talmudic instruction.

We omit here two Talmudic cases cited by Maharil $[\mathrm{K}],{ }^{17}$ in which the Talmudic sage Shmuel argues that when there are groups frequently traveling from one place to the other there is more likelihood that the plague will travel along. Finally, Maharil comes to his conclusion:

[L] All of this supports that which we said [above, Section B: "The destroyer] does not distinguish [between the righteous and the wicked.] It is therefore apparent that there is no prohibition [to flee a plagued city].

It is clear from the responsum that fleeing was common. The questioner, himself a scholar, asked Maharil how this common practice squares with the belief that no one dies before their time - which "implies, somewhat, that one should not flee." The main concern of Maharil's answer is that death need not be foreordained, so fleeing is efficacious. In support of this point, he marshals different kinds of arguments and sources: passages from the Babylonian and Palestinian Talmuds, verses from Scripture, common practice, the behavior of leading sages, oral traditions from living rabbis, and Sefer Hasidim.

In Section J of the responsum, the baraita that instructs, "gather your feet," appears. Although this instruction does not contradict Maharil's earlier assertion that human beings can act to avoid death, the directive does contradict the specific action of fleeing plague rather than sheltering in place. Addressing

17 The omitted section [K] reads as follows: “In [вт] Tractate Ta'anit [21b]: 'There is a pestilence in Bei Hozai - we decree a fast, even though it is very far, for there are frequent caravans.' It further states there: [Rabbi Yehudah] said to Shmuel: There is pestilence among the swine - we decree a fast for their innards are similar to that of humans."' 
this issue, Maharil refers to a teaching by Rabbi Shalom Neustadt, Maharil's teacher and a leading Ashkenzic sage at the turn of the 15th century. This teaching reconciles the directive to stay at home with the common practice of fleeing by differentiating between different stages of the outbreak.

It seems that Rabbi Shalom Neustadt himself was bothered by the exegetical problem of the disparity between the behavior he witnessed and the Talmudic directive. He resolved the problem by positing that the baraita in the Talmud and the common practice address different stages of an outbreak. At an early stage, fleeing is acceptable. The directive about staying inside refers to a later stage of the plague. Maharil does not explicitly mention whether the practice to flee that he observed was indeed limited to the early stages of plague. It stands to reason that this was indeed considered the right moment to do so. For one, a well-known adage about plagues at the time was "Flee quickly, far away, stay long."18 Jews may have shared the belief in this piece of common wisdom to flee quickly. Moreover, Jews faced an added risk of antiJewish violence on the roads, as the next source discussed in this article explicitly mentions. ${ }^{19}$ This particular danger increased when the plague evolved, especially if the plague was perceived as having begun among Jews. ${ }^{20}$

It seems that this is also the reason for introducing the passage from Вт Ta'anit (Section K). Once the plague has taken hold, it can pass from one place to another by means of traveling groups. At that point, fleeing is no longer efficacious, and so sheltering in place is the proper course of action.

Both these late-medieval sources attest to the phenomenon of fleeing plague and address its normative dimensions. The first, Sefer Hasidim, does not even mention the conflicting Talmudic dictum, whereas the other, Maharil's responsum, tangentially addresses the conflict and resolves it with an oral tradition from his (still-living) master, Rabbi Shalom Neustadt, who alone seems

18 See Byrne, supra note 10, "Flight", 146.

19 The source in question is Rabbi Shlomo Luria. See infra note 21.2: "Especially after the plague has taken hold, the danger to those who flee among the gentiles is greater than the danger of the plague, as is well known, due to our abundant sins. However, at the beginning it is good to flee."

20 There is some historical evidence that such violence was indeed a real risk, especially when epidemics that started in the Jewish areas began spreading to other parts.

See, for instance, this letter about Kazimierz, the Jewish area outside Krakow, during the plague of 1588 . The writer explains that the Jews were worried about violence, “...because among Jews [in Kazimierz] there was bad air, and in the town [Krakow proper] not, therefore no Jews could show themselves in the town or on the field, because hajduks [brigands] were knocking everything down." Bernard Weinryb, "A Pekel Briv in Yiddish Fun Yohr 1588”, 2 Historishe Shriftn fun YIVO (1937), 61 (Yiddish). 
to have dealt with the exegetical, halakhic conflict primarily. Neither source is a typical prescriptive halakhic text in the sense that neither one is a systematic, methodical treatment of a specific area of halakhah. Sefer Hasidim deals mainly with practices, and responsa treat particular complex cases but do not treat halakhic topics in a general manner. In the prevalent halakhic literature, the question of how to act during plague is not addressed at all. It would enter mainstream halakhic discourse only in 16th-century Poland.

\section{4 16th-century Polish Halakhists}

Polish halakhists belonged to the Ashkenazic halakhic tradition, which did not accept the medieval halakhic codes mentioned in Part 2 of this article as ultimately authoritative, and thus had no consolidated, post-Talmudic corpus by which to examine each Talmudic dictum. Consequently, the distinctions between different types of knowledge were not too rigid. Even if Ashkenazic halakhists agreed that the Talmudic directives regarding plague were nonbinding, the directives still indicate that what the Talmud viewed as proper behavior could not be ignored by anyone presuming to follow the Talmud's guidance in their lives. Thus, although fleeing from plagues does not appear in medieval halakhic codes, 16th-century Ashkenazic halakhists address it as a halakhic problem, because for them, the Talmudic discussion itself was a sufficient reason to take it seriously.

Precisely because this case had ambiguous legal significance and did not belong to any distinct genre of text, it serves to highlight some of the trends that comprise the halakhic revolution as a literary revolution in 16th-century Poland, especially as reflected in the writings of two of its leading lights: Rabbi Shlomo Luria (Maharshal, d. 1574) and Rema.

\subsection{Maharshal (Rabbi Shlomo Luria)}

Rabbi Shlomo Luria's most important halakhic work is Yam shel Shlomo. ${ }^{21}$ It follows the order of the Talmud and, after analyzing Talmudic discussions, brings them to a halakhic conclusion. In the volume on Bava Qamma, he devotes a section (chapter $6 \S 26$ ) to the plague passage. The influence of Rabbi Shalom Neustadt, who differentiated between fleeing early and late, is already discernible in the heading: "The Law of a Plagued City: Before it takes hold one is obligated to flee, and once it takes hold, one should gather his feet into his

21 On Maharshal, see Rafeld, Rabbi Shlomo Luria and the Sea of Shlomo, (PhD. Diss., Bar Ilan University, 1991) (Hebrew). 
house." Maharshal begins his analysis by copying the Talmudic passage, concluding with the dictum, "If there is famine in the city, scatter your feet." $\mathrm{He}$ then begins his discussion:

Some wish to derive from here that we do not say "scatter your feet" with respect to plague, and that it is forbidden to flee. It is also forbidden because of danger, for we say, "gather your feet," and "one should not walk in the middle of the road," so how can he flee? Moreover, we say in the chapter "Zeh Borer" [вт Sanhedrin 29a]: 'Seven years there was a pestilence, yet no one died before his time.' However, I found written in the name of the great halakhists that it is permitted [to flee]. ${ }^{22}$

At this stage, Maharshal presents a reordered paraphrase of Maharil's responsum (whose author is not cited by name) with some minor additions. ${ }^{23}$ The novelty of Maharshal's approach is not only that he rearranged the contents of Maharil's responsum, but that he reframed it, removing it from a practicaltheological context and embedding it in a direct halakhic-exegetical relationship with the Talmudic statements. Given his larger project - returning to the text of Talmud and reexamining its instructions - he could not do what so many of his predecessors had done and simply ignore this passage. He therefore dismantled, rearranged, and reassembled Maharil's responsum in a way that places the text of the Talmud at the center of the discussion of proper

22 Rabbi Shlomo Luria, Sefer Yam Shel Shlomo Al Masekhet Bava Qamma:Peraqim 1-6 (Lakewood, NJ: Makhon Mishnat Rabbi Aharon, 2020), 6:26, 385 .

23 There are three such additions:

After explaining why "there is good reason to flee," Maharshal adds: "Nevertheless, if he can save people on his own or with his money, heaven forfend that he hold himself back and detach himself from public distress. He will not witness the comfort of Zion." Here, Maharshal introduces a new variable into the discussion: the ability to help others.

As evidenced by 16th-century letters from Krakow, the more important and powerful community leaders did indeed flee, but other community functionaries, such as the notary, stayed in the city to help those left behind. See Weinryb, supra note 19.

Maharshal's paraphrase of Rabbi Shalom Neustadt's distinction concludes: "We likewise say: 'All roads are presumed dangerous.' Therefore, it is not good to flee." He then adds: "Especially after the plague has taken hold, the danger to those who flee among the gentiles is greater than the danger of the plague, as is well known, due to our abundant sins. However, at the beginning it is good to flee. As to why Rava did not flee, we must say that perhaps he was unsuccessful."

The third addition concerns the parts of Maharil's responsum on mourning during times of panic and plague. 
conduct during plague. A reader unfamiliar with Maharil's responsum would not even recognize Maharshal's craftsmanship.

A careful reading of the opening lines of the unit discloses the agenda guiding the composition. It begins with the passage from the Talmud, which contrasts plague ("gather your feet") and famine ("scatter your feet"). This seems to imply that fleeing from plague is forbidden. Moreover, even if the Talmud merely advises against fleeing plague, but does not prohibit it outright, fleeing would still be a dangerous undertaking to be avoided. Finally, the Talmud states in Sanhedrin that no one dies before their time - so there is no reason to flee.

Having conceptualized fleeing from plague, Maharshal cited the view and prooftexts - material that he took from Maharil — of the "great halakhists" who permit fleeing. He resolves the tension by introducing Rabbi Shalom Neustadt's temporal distinction, likewise taken from Maharil. Yet although all the individual components are taken from Maharil, the result is a wholly different kind of composition: a textual analysis with the Talmud at the center and all the other sources and traditions converted into a counterweight, until a distinction ultimately harmonizes the sources and enables their coexistence.

Admittedly, certain elements of the Maharshal's reframing are dictated by the nature of the composition. It is only natural that the discussion in Yam shel Shlomo, a running analysis of the Talmud, would begin with the Talmudic passage that triggers the discussion. Beyond that, however, Maharshal could have found other ways to structure the discussion, without highlighting the contradiction between the Talmudic dictum and the widespread custom, and without stating from the outset that flight from plague is forbidden according to the plain meaning of the Talmud. He clearly chose a literary framing that reflects his reassertion of the Talmud and its textual centrality, even when it comes to passages that had never been considered binding.

Finally, we arrive at Maharshal's halakhic conclusion: "It is therefore apparent that if plague comes to the city, one is obligated to flee if he has the wherewithal, unless he has already contracted the plague and been cured, for, then, everyone says that he has nothing to fear." ${ }^{24}$ Astonishingly, his conclusion ignores the distinction between the time before and after the plague takes hold. Moreover, unlike Maharil, who wrote, "it is good to flee," and, "it is therefore apparent that there is no prohibition," Maharshal states unequivocally: "One is obligated to flee."

At first glance, this contradicts the heading for the unit, which repeats the distinction of Rabbi Shalom Neustadt. This is easily resolved, however: it is 
presumed that the heading was not composed by the author himself;:25 Yam shel Shlomo was first printed in Prague in 1616, forty years after Maharshal's death.

To sum up, Maharshal devoted a unit of his work on Bava Qamma to the directives of the Talmud for times of plague. In doing so, he established them, for the first time, as Talmudic halakhah that must be accounted for. Nevertheless, although the contradiction between the Talmudic directives and common practice provides the context for Maharshal's discussion, he did not invest much effort in resolving the contradiction. He contented himself with reorganizing Maharil's responsum, without adding anything new. In practice, he did not challenge the accepted custom to flee and did not even limit flight to the early stages of the outbreak.

\subsection{Rema}

Maharshal's cousin and contemporary, Rema, creatively addresses the problem of fleeing plague in two halakhic works he composed, taking another step forward from a literary perspective; he was the first to integrate this directive into the classic halakhic literature - specifically, into the formative codes of the rabbinic curriculum, Tur and Shulhan Arukh. ${ }^{26}$ In Darkhei Moshe, Rema's commentary on Tur (Yoreh De'ah 116:5), ${ }^{27}$ he wrote:

25 Meir Rafeld has shown that the synoptic headings in Yam Shel Shlomo often do not reflect the halakhic contents in the body of the unit. The clearest demonstration of this is a comment that appears toward the end of Yam Shel Shlomo on Bava Qamma, in which Maharshal's son, Yehiel, reports that his father had a disciple, Rabbi Avraham of Ostroh, write the synopses, as Maharshal himself deemed it a waste of his time. See: Meir Rafeld, "Maharshal (R. Shlomo Luria) and the Authority of Abridged Halakhic Books", 18-19 Shenaton ha-Mishpat ha-Ivri (1992-1993), 427 (Hebrew).

26 Shulhan Arukh was authored by Rabbi Yosef Karo (see infra note 32) in his later years, and first printed in Venice in 1565 . He wrote this relatively short work on the basis of his earlier work, Beit Yosef, a revolutionary halakhic code, composed as a commentary on the 14th-century Sefer Ha-Turim ("Tur") of Rabbi Ya'aqov ben Asher, who reorganized material from earlier codes into a practical work. In Shulhan Arukh, Karo sought to unify all Jewish communities under a single halakhah. It is not clear whether he intended Shulhan Arukh as a source for halakhic rulings or as an index to his magnum opus, Beit Yosef. Within a few years, Shulhan Arukh became the most basic halakhic work of early modernity, and it continues to hold this status even today, to the extent that "Shulhan Arukh" has become synonymous with "halakhah" itself. See Isadore Twersky, "The Shulchan Arukh: Enduring Code of Jewish Law," in Judah Goldin (ed.), The Jewish Expression (New Haven: Yale University Press, 1976); Haim Tchernowitz, The history of the Jewish codes vol. 3 (New York, 1946-1947) (Hebrew).

27 Darkhei Moshe was first printed, and only partially, in 1692. Nevertheless, his disciples quote and mention the work, which clearly circulated within Polish rabbinic circles in the late 16 th and 17 th centuries. 
Maharil wrote in responsum $\S 30^{28}$ that it is good to flee in times of plague, may it not befall us, and that one should flee at the beginning, not the end... It is likewise written in Zohar, Parashat Vayera Elav, that one should flee the city. And even though we say in the Talmud, "If there is famine in the city, scatter your feet," it seems to me that fleeing is certainly better, but if one can go inside and not leave [he need not flee]; if not, he is required to flee. And the custom of Israel is Torah.

The section of Tur on which Rema is commenting is a compilation of things forbidden because they are dangerous for one's health and safety. Rema supplements Tur's collection of precautions with prohibitions based on precautions from texts and traditions in his milieu. It is here that he discusses what to do when plague strikes.

Rema begins by citing Maharil's responsum as a halakhic source with a straightforward ruling. He then introduces and draws support from a new source: Zohar, ${ }^{29}$ which had just been printed for the first time in 1558. Rema does not provide a specific citation, but presumably he is referring to Zohar's comments on the angel's command to Lot to flee the condemned city of Sodom: "Flee for your life! Do not look behind you, nor stop anywhere in the plain; flee to the hills, lest you be swept away" (Genesis 19:17):

Come and see: When judgment prevails in the world, it is said that a person should not be found in the marketplace, for when judgment prevails, it does not distinguish between the innocent and the guilty, so he should not look there. It is also said that this is why Noah was placed in an ark, so he would not examine the world when judgment is being executed. And it is written: "And none of you shall go out of the opening of his house until the morning" - until judgment is done. Therefore: "Flee for your life! Do not look behind you...." ${ }^{30}$

28 This should be $\S 50$, which is where this responsum appears in the Cremona, 1556 edition of Maharil's Responsa that Rema used, see supra, note 13 .

29 Zohar is a collection of esoteric theological literature composed in Spain in the 13th century and attributed to Rabbi Shimon bar Yohai, a Palestinian sage of the 2nd century. Zohar was first printed in the order of the weekly Torah readings, in two parallel editions: Mantua $155^{8}$ and Cremona 1559. The communities of Ashkenaz and Poland used the Cremona edition. See Yiẓhak Yudlow, "On Books, Printing, and Publishers" in Yosef Eliyahu Movshovitz (ed.), The Book vol 2 (Jerusalem: Mossad ha-Rav Kook, 2008), 558-559 (Hebrew).

Zohar, 281 (Cremona edition), 107b (Mantua edition). 
According to Zohar, the reason for avoiding the marketplace - a metonym for any public place - and the reason for fleeing to a different city is one and the same: it is dangerous to witness a time of punishment that does not distinguish the guilty from the innocent, for anyone present could be included in this harsh sentence. Rema uses this source to resolve the exegetical conundrum presented by the Talmudic directive and to produce a new interpretation: it is not forbidden to flee the city, but it is dangerous to go out into its streets. The best course of action is to flee the city completely. The sages' directive to "gather your feet" applies only to one who can go indoors and not go out into the street at all. If one is unable to remain indoors, he must flee. Rema thus reaches the same conclusion as Maharshal, albeit by a different route.

Rema then addresses the conflict between the Talmudic directive to flee and both Maharil and Zohar, the two sources he cited first. Rema offers his own novel interpretation to resolve the difficulty, rather than Maharil's earlier attempt to resolve it by limiting the Talmudic instruction to a particular stage of the plague. Rema mentions Maharil's distinction without noting that it was intended as a resolution of the difficulty. Rema was not satisfied with the solution of distinguishing between two stages of plague, perhaps because this distinction is not made in the text itself and its logic is not readily apparent. Instead, he offers a more fundamental resolution that solves the contradiction without positing unstated distinctions and limitations: "Gather your feet" and stay home, because the street is a place of danger that must be avoided. And if one can avoid the street by leaving the city completely, it is an even better option.

Rema concludes with a broad statement justifying his ruling: Jewish custom has the status of Torah. Thus, in this short paragraph, Rema amalgamates four disparate elements - Maharil's responsum, the Zoharic passage, his own novel interpretation of the Talmudic statement, and the principle that "the custom of Israel is Torah" - within a single halakhic discourse, fashioning them into a cohesive approach. ${ }^{31}$ The last element, Rema's appeal to the authority of

31 For background on the status of custom in the Jewish tradition, see the first two volumes of Daniel Sperber, Minhagei Israel (Jerusalem: Mossad ha-Rav Kook , 1990-1991) (Hebrew); Menachem Elon, Mishpat Ivri vol 1 (Jerusalem: Magnes, 1978), 714-717 (Hebrew).

On the primacy of custom in Ashkenaz, see Dinari, supra note 11, 297-302; Israel TaShma, The Ancient Ashkenazic Custom (Jerusalem: Magnes, 1992), 16-22 (Hebrew); Israel Ta-Shma, "Halakhah, Custom and Reality in Ashkenaz, 1000-1350" in Kneset Mehkarim (Jerusalem: Bialik, 2005), 9-10, 16, and 93-103 (Hebrew); Israel Ta-Shma, "Halakhah Custom and Tradition in the Jewry of Ashkenaz in the 11th-12th Centuries", 2 Sidra 2 (1987), 145 (Hebrew); see also Talya Fishman, Becoming the People of the Talmud (Philadelphia: University of Pennsylvania Press, 2011), 177-178. 
established custom as Torah, is formulated as a broad, overarching principle and deployed boldly as Rema's "closing argument" in support of his ruling that one must flee plague.

Although Rema frequently appeals to the authority of custom, only rarely does he assert that "the custom of Israel is Torah" 32 (one other place being in Darkhei Moshe, and another in his glosses to Shulhan Arukh). Each time the expression appears, it is to bolster a tradition that has no anchor in any source and lacks halakhic logic. ${ }^{33}$ The use of such a rare expression in the present case demands explanation.

Rema's appeal to custom-as-Torah here can be explained in light of his attitude toward Zoharic literature. In principle, Rema agrees with the view ${ }^{34}$ that one should adopt the position of Zohar only when it does not conflict with explicit rulings of the Talmud or halakhic codes. ${ }^{35}$ But Rema's definition of "Talmud" in this context is expansive, granting weight to a broad spectrum of rabbinic literature. Rema also introduces another source of authority: custom. For instance, in one case where Zohar conflicted with one of these late antique rabbinic works that he defined as "Talmud," and the Babylonian Talmud itself took no position, Rema decided against Zohar, and in favor of the source that agreed with the prevalent custom, writing: "we need not concern

32 See Darkhei Moshe, Orah Hayim 298:2 (where Rema's assertion likewise bolsters a practice that aligns with Zohar) and Rema's gloss to Shulhan Arukh, Yoreh De'ah 242:14. The phrase also appears twice in Responsa Rema: $§ \S 81$ and 132:3. Rema's source for the phrase is apparently Rabbi Ya'aqov ibn Habib, as he quotes it in his name (Darkhei Moshe, Yoreh De'ah 65:10). A similar phrase, "the custom of our fathers is Torah," is common in medieval Ashkenaz, but it differs in meaning, slightly or significantly, from the expression "the custom of Israel is Torah," which first appears in the writings of Sephardic rabbis. See Shmuel Ashkenazi, Alfa Beta Kadmita de-Shmuel Ze'ira, (Shmuel Avraham Tefilinsky (ed.), Jerusalem: NP, 200o], 210-217. We thank Prof. Simcha Emanuel for pointing out the difference between these two expressions.

33 In contrast, the expression, "the custom of our fathers is Torah," which Rema uses several times in his works, is used in the context of traditions that have no clear source but have some basis, and whose logic can be explained.

34 This is the view of Rabbi Yosef Karo (d. 1575). Rabbi Karo was born in Spain before the expulsion of 1492, and studied in Constantinople and Adrianople (Edirne) before moving to Safed, where he lived most of his life. He wrote Shulhan Arukh, see supra note 23. On Karo, see Mor Altschuler The Life of Maran Yosef Karo (Tel-Aviv: TAU Press, 2016); Meir Benayahu, Yosef My Chosen One (Jerusalem: Yad ha-Rav Nissim, 1991) (Hebrew); Yekutiel Yehuda Greenwald, The Life of Rabbi Yosef Karo (New York, 1953) (Hebrew).

35 Eliezer Brodt studied the status of Zohar in Rema's works and identified thirteen mentions of Zohar in Darkhei Moshe. In six of those instances, Rema rules explicitly against Zohar. See Eliezer Brodt, "Halachic Commentaries to the Shulchan Aruch on Orach Chayim from Ashkenaz and Poland in the Seventeenth Century" (Ph.D. dissertation, Ramat Gan: Bar-Ian University, 2015), 166-167. 
ourselves with the mysteries of Zohar that conflict with it, since the custom has already spread." 36

Thus, Rema indicates that the main reason for his ruling is "since the custom has already spread." According to Rema, when assessing the literary evidence to decide between Zohar and a minor Talmudic tractate, prevailing custom should carry significant normative weight.

In his directives for times of plague, Rema appeals to custom-as-Torah to justify his Zohar-influenced interpretation of the Talmudic directives to "gather one's feet." Even if the plain meaning of the Talmud were normally given greater normative weight than a strained interpretation that harmonizes with Zohar, "the custom of Israel is Torah," and it is inconceivable that custom would contradict the Talmud.

It is not clear what Rema's position is regarding the limitation he cites in the name of Maharil to flee at the beginning, not the end. Rema's own novel interpretation of the Talmudic passage renders superfluous the interpretation that Maharil proposed in the name of Rabbi Shalom Neustadt, but perhaps Rema was citing Maharil as a halakhic opinion, not a Talmudic interpretation. Thus, it is possible that Rema rejects Maharil's interpretation but remains bound by his practical ruling about fleeing at the beginning. Rema's interpretive freedom was much greater than his freedom to determine practice, so although he did not agree with the basis for the ruling, he nevertheless determined the law in accordance with that view. ${ }^{37}$

Rema would go on to incorporate this as law in Mapah, his glosses to Shulhan Arukh, at the end of a unit that lists dangers to be avoided. He writes: "They further wrote that one should flee the city when there is plague in the city, and one should leave the city at the beginning of the plague, not the end." Rema thus "filled in" what R. Yosef Karo did not include in Shulhan Arukh. Precisely because this subject had not been addressed in earlier halakhic sources, it allows us to see how Rema reincorporated as halakhah and within the rubric of Shulhan Arukh what earlier halakhists had not considered halakhah and never codified. At the same time, the vague nature of the law was what allowed Rema in Darkhei Moshe to uphold fleeing with the statement, "the custom of Israel is Torah."

36 Darkhei Moshe, Orah Hayim 59:2.

37 Alternatively, it is possible that Rema rejects Rabbi Shalom Neustadt's interpretation because it did not reflect the reality he observed. If people were not differentiating their behavior based on the stage of the plague, Rabbi Shalom Neustadt's interpretation, despite being textually coherent, does not resolve the conflict between the Talmudic directives and common practice. 
The halakhah as formulated in the gloss to Shulhan Arukh is faithful to Maharil's responsum in both content and style; Rema does not write that one must flee during plague, but that one should flee. Nor does Rema repeat the forceful expression that he used in Darkhei Moshe: "the custom of Israel is Torah."

Rema ostensibly stepped back from the approach he forged in Darkhei Moshe in that he limited fleeing to the conditions articulated by Rabbi Shalom Neustadt. This disparity between Rema's glosses in Mapah and Darkhei Moshe can be explained as follows: in Mapah, his glosses to Shulhan Arukh, Rema is more cautious about offending the honor of his predecessors and avoids farreaching innovations, because his objective in the glosses is to establish the accepted custom. Mapah does not necessarily reflect Rema's personal view of each halakhah. Rather, it purports to reflect the view that best represents the Ashkenazic tradition. This contrasts with Darkhei Moshe, which is a more personal work that incorporates Rema's novel interpretation.

Thus, the constraints of literary genre account for the differences between Mapah and Darkhei Moshe in both style and substance. Mapah is about tabulating majority opinion, forging compromises, and achieving a consensus that reflects the greatest common denominator of Ashkenazic practice. In the present case, Rema ignores his own interpretation in Darkhei Moshe and instead adopts the earlier and more representative ruling of Maharil. Note that the distinction in Sefer Hasidim between groups, which must not flee, and individuals, who may, is not mentioned at all by Rema, although it is mentioned in Maharil's responsum.

\section{Jewish Folk Literature in Poland in the 16th Century}

Contemporary with Maharshal and Rema was a rabbi named Yehiel ben Yedidiah of Lublin, known as R. Michel Moravchik (a moniker attesting to his Moravian origins). Whatever is known about his life comes from the four books that he published in Krakow during a brief period of five years at most, during the last quarter of the 16th century: Minhah Hadashah (1577), an anthology of interpretations of Tractate Avot of the Mishnah; Peirush Birkat HaMazon (1580), a commentary on the benediction after meals and traditional hymns sung during festive meals; Gezeirah MiMedinat Osterreich (1581), a chronicle of the antiJewish decrees in Vienna in 1421-1422; and Seder Berakhot (1582), a halakhic monograph on the laws of benedictions. It is evident from several places in his writings that R. Michel served as a darshan (preacher, homilist) in various 
communities. Occasionally, the printed material preserves a trace of the original oral presentation of his sermons.

Several features distinguish his first work, Minhah Hadashah. Foremost is its exceptionally frequent use of Zoharic literature, including many complete, exact quotations Despite its prominence in the anthology, the name Zohar does not appear on the title page alongside the other commentaries that serve as sources for the work (for Zohar does not include a commentary on Tractate Avot). But the introduction of the anthology describes that it contains: "Dicta from the Book of Zohar that are needed for this tractate; Talmud and aggadah; Midrash Rabbah and [Midrash] Zuta; and Avot de-Rabbi Natan."

The appearance of Zohar at the beginning of this list, before the rest of rabbinic literature, is not unwarranted, as its lofty status within this work is obvious. Whereas the Talmud and Midrashim are mentioned infrequently and synoptically, more than thirty Zohar passages are quoted verbatim (and over ten more in a collection of passages appended to the book). It seems that Minhah Hadashah was the first printed work to be directly influenced by the printing of Zohar a few years earlier.

Yet, in his treatment of the phenomenon of fleeing plague, R. Michel Moravchik does not mention the Zohar passage cited by Rema in (the as-yet unpublished) Darkhei Moshe. Rather, he resolves the issue through homiletic moralizing:

Nowadays we flee the city due to disturbance of the air, may God protect us, without realizing that it was sent providentially from God [...] Rather, it seems that the fact that we wander, roam, and experience displacement subdues our uncircumcised hearts and our stiff necks, such that the displacement and wandering becomes atonement for all of our sins. One should not be so bold as to stand before his King when He is angry with him; hide yourself for a while, until the tempest (za'am) has passed. ${ }^{38}$ You also find in the Torah: "None of you shall go out of the opening of his house until the morning." Once power has been given to the destroyer, he does not distinguish between the righteous and the wicked. ${ }^{39}[\ldots]$ Therefore, distancing is good, and exile, wandering, and displacement atone and halt [God's] anger. ${ }^{40}$

38 Isaiah 26:20. As we saw, the Talmud also uses this verse as a prooftext for its directive to "gather your feet."

39 Exodus 12:22, as cited in вт Bava Qamma 6oa-b, which we saw above.

40 Rabbi Yehiel (Michel) Moravchik, Minhah Hadashah (Krakow: Isaac Prostitz, 1577), 59b. 
In contrast to Rema and Maharshal, R. Michel addresses the problem of escaping foreordained fate and the impossibility of evading an omnipresent God. He explains the common custom with moralistic, homiletic thinking: he avers that for someone to remain in place when the King is angry at him expresses impudence, and he explains that going indoors (as recommended by the prooftexts that are themselves paraphrases of the Bava Qamma passage) is a symbolic act of hiding from God - and that symbolism is accomplished by fleeing as well. Finally, there is moral logic in fleeing, because through exile and displacement one can atone for sins by the suffering they cause. At the end of the passage, he includes the principle that appeared in Maharil's responsum: the efficacy of flight from danger is predicated on the assertion that, "Once power has been given to the destroyer, he does not distinguish between the righteous and the wicked." Flight is therefore not a denial of God's providence. ${ }^{41}$

This passage from Minhah Hadashah introduces a different audience than the ones with which we are familiar from halakhic literature. This audience, which had its own intellectual climate, is sparsely documented, and what little material exists about it can be found in moralistic and homiletic literature that has not garnered much scholarly attention, like the works of R. Michel. For members of this stratum, the key question is the practical one: when plague comes, what should we do? Theological questions about providence versus

41 The notion of displacement as a form of atonement appears in a work by Rabbi Moshe de Trani (Mabit), one of the best-known sages of Safed in his generation. The work, Beit Elohim, was published in 1576 , the same year that Minhah Hadashah was sent to print (according to its colophon). Mabit, like his Sephardic predecessors (see supra note 5), addressed the practice of fleeing plague in context of the broader theological question of preordained fate versus human endeavor, but he introduces a new element, the expiative value of exile:

Some are absolutely bound by their death sentence, whether they remain in that place or... flee... And some are bound by their sentence if they remain in that place, but if they flee... fleeing is sufficient; the pain he experiences is considered exile, and he is saved... [Rabbi Moshe de Trani, Beit Elohim (Venice: Giovanni di Gara, 1576), Sha'ar HaTefilah, chapter 16, 18a].

It is difficult to determine whether R. Michel got the idea of applying the expiative value of exile from Mabit's explanation for fleeing the plague. On one hand, the idea that the pain of exile saves from death by plague is not attested in any source earlier than Beit Elohim, and Minhah Hadashah does make frequent use of Sephardic homiletic works that were then being printed in Italy. On the other hand, the basic idea of the expiative value of exile was not new or original, so it is possible that two contemporary thinkers thought of it independently. Moreover, the idea appears, in an incipient form, in Sefer Hasidim. Recall that, according to Sefer Hasidim, traveling groups of merchants will not avoid the plague, but individuals can sometimes escape by fleeing. 
human endeavor and halakhic-exegetical questions about how to harmonize and assign normative weight to various sources fade into the background. Working with the same building blocks as halakhic literature - common practice, Talmudic passages, biblical prooftexts, and late medieval treatments of the issue - R. Michel uses allegory, symbolic action, and ideas about the redeeming value of suffering to build the moral case for fleeing from plague. The organizing logic of the Minhah Hadashah passage is the logic of the homily.

The Talmud prescribes a specific action - "gather your feet" — during times of plague. This directive was left out of halakhic works until the end of the medieval era. By then, another practice had emerged during times of plague: fleeing. The only source to discuss the practice of fleeing prior to the $15^{\text {th }}$ century is Sefer Hasidim, a non-halakhic work, which determines that individuals can successfully flee an epidemic, but traveling groups cannot. The nature of this discussion is ambiguous: it could either be a consideration of the permissibility of fleeing or of the efficacy of doing so, and it includes theological, legal, moral, and practical aspects that are not always differentiated or made explicit.

In the 15th century, the practice appears in an unambiguously halakhic context: a responsum of Maharil that addresses the permissibility of fleeing from plague. The responsum brings together disparate sources and a variety of discourses without distinguishing them sharply: textual and oral, legal and theological, observed practice, custom, and law. The passage from the Talmud reemerges here, and its conflict with the common practice is registered and resolved by means of a distinction between various stages of a plague.

In the 16th century, with the stronger distinction between different literary genres that resulted, among others, from the invention of print, variations in approach are determined by the type of genre in which the scholar is working. There is less fluidity and co-occurrence of different types of sources. Even when sources co-occur, they are translated and embedded in the language, discourse, and mode of reasoning of the genre at hand, be it the intellectual argumentation of a textual halakhic interpretation of the Talmud, a dense commentary on a legal code, a consensus-based gloss on a prescriptive code, or the associative moral logic of a homily.

Maharshal, writing an analytical commentary on the Talmud, centers his discussion around the Talmudic passage and reorganizes the contents of 
Maharil's responsum accordingly. Despite reasserting the centrality of the Talmud as a halakhic text and resolving the conflict between text and practice by distinguishing different stages of plague, he does not adopt the distinction in his conclusion, which follows the common practice and asserts that one must flee.

In Darkhei Moshe, Rema's personal update of Tur's collection of sources about avoiding danger, Rema begins with Maharil but soon introduces Zohar, which he uses to suggest his own, somewhat forced resolution of the conflict between the Talmud and common practice, bolstering his reading by declaring the normative status of custom.

In his gloss to Shulhan Arukh, a halakhic code with a more universal ambition, Rema leaves out his own interpretation, the Zohar passage on which it is based, and the direct appeal to the normative value of custom. What remains is only the temporal distinction between stages of plague, cited by Maharil in the name of Rabbi Shalom Neustadt.

Finally, we examined yet another genre: the homily. This popular literary form allows for a more associative combination of halakhah, textual exegesis, and theology, including some of the same sources used by Rema and Maharshal, within a rhetorical discourse comprised of parables, symbolism, and wordplay, addressing itself to the practical question of whether fleeing plague is effective. The fluidity of the homily and the fact that it is unambiguously outside the legal realm are not coincidental.

In the early 17th century, two Polish commentators on the Talmud addressed how "gather your feet" is related to the practice of fleeing: Rabbi Avraham Hayim Schor (d. 1632), a disciple of Rema, in Torat Hayim ${ }^{42}$ and Rabbi Shmuel Eliezer HaLevi Eidels (Maharsha, d. 1631), in Hiddushei Aggadot. ${ }^{43}$ Like their predecessors, they accepted the practice of fleeing plague, but despite the Talmudic passage that prescribes fleeing in cases of famine and sheltering at home for plague, they did not consider the possibility that the text contradicts common practice.

R. Schor asks why the Talmud does not say, "If there is plague in the city, scatter your feet," as it does for famine, wondering why the Talmud does not say what it certainly means, which is that fleeing is recommended. According to his answer, the Talmud must have considered it obvious that fleeing is

42 Rabbi Avraham Ḥayim Schor (Lublin: Tzvi Bar Avraham Kalonymous Yaffa, 1624), 27b, s.v. "dever ba'ir".

43 Rabbi Shmuel Eliezer HaLevi Eidels (Lublin: Tzvi Bar Avraham Kalonymous Yaffa, 1627), 50a, s.v. "sham dever ba'ir". Note that the two works were printed by the same printer within three years of one another. 
recommended, and only meant to add that whoever does not wish to flee plague may instead "gather his feet" and remain at home, an option that is not available during famine, when only fleeing will do. ${ }^{44}$

Maharsha's formulation is particularly striking: he claims that the Talmudic statement cannot be understood according to what he acknowledges is its most straightforward meaning, namely, that "gather your feet" excludes the option of fleeing. Rather, he asserts, "It is impossible to understand it in this manner, for it is certainly good to 'scatter his feet' and escape with his life when there is plague in the city." He therefore explains that "scatter your feet" must certainly apply only to one who has neglected to flee the city.

Neither R. Schor nor Maharsha mentions names, but both explain the passage in accordance with Rema's explanation in Darkhei Moshe. R. Schor adds as an alternative the distinction between the beginning of the plague and later points in time, as suggested by Maharil in the $15^{\text {th }}$ century, repeated by Maharshal in the 16th, and as codified by Rema in the same century in his gloss on Shulhan Arukh. Both Torat Hayim and Hiddushei Aggadot belong to the genre of commentaries on the Talmud. Neither is a halakhic work; their concern was textual, not practical. Moreover, it was obvious to these sages that the Talmud meant to say exactly what Rema said, which accorded exactly with what they did in practice. Rather than solving any halakhic issue, their sole goal was to make sense of a peculiar passage whose plain meaning was rendered inconceivable by the developments within the Ashkenazic halakhic literature reviewed in this article.

It was in the 16th century that heirs to an Ashkenazic tradition who mixed different kinds of sources, discourses, and authority, without sharply distinguishing between them, reworked and rearticulated this tradition within different genres, each with its own type of reasoning and argumentation, its own type of authority, and its own system for determining the significance and relative value of disparate sources. There are basic commonalities in all the 16thcentury Ashkenazic sources we analyzed. Each one respects the practice of fleeing, and each one addresses, explicitly or implicitly, the traditions inherited from the late medieval era, specifically, Maharil's responsum. Yet each has its own modes of discourse and argumentation, its own literary function, its own way of claiming authority, and its own manner of embedding and reworking the inherited materials. Along the way, the Ashkenazic tradition gains clarity

44 R. Schor then offers an alternative explanation that was already taught by Maharil in the name of his teacher: "gather your feet" refers to when plague has already taken hold, whereas fleeing is the proper course of action only before it takes hold. R. Schor did not even raise the possibility that the Talmud meant to prohibit fleeing during the plague. 
and definition. By the same token, however, the interpretive fluidity and fertile ambiguity that characterize earlier Ashkenazic treatments of the practice of fleeing epidemics - an issue that, at its core, amalgamates law, lore, theological speculation, and practical considerations — are lost. 